\title{
PENGEMBANGAN INSTRUMEN KEMAMPUAN BERPIKIR KRITIS DAN KETERAMPILAN PROSES SAINS SISWA KELAS V SD
}

\author{
N.P.A.T. Ariyani ${ }^{1}$, I.W. Suastra ${ }^{2}$, P.B. Adnyana $^{3}$ \\ ${ }^{123}$ Program Studi Pendidikan Dasar \\ Universitas Pendidikan Ganesha \\ Singaraja, Indonesia
}

e-mail: ayu.tina@undiksha.ac.id ${ }^{1}$, iwsuastra@undiksha.ac.id ${ }^{2}, \underline{\text { budi@undiksha.ac.id }}^{3}$

\begin{abstract}
Abstrak
Penelitian ini bertujuan untuk mengetahui dan mendeskripsikan: 1) unsur-unsur tahapan pengembangan instrumen kemampuan berpikir kritis dan keterampilan proses sains; 2) validitas empirik instrumen kemampuan berpikir kritis dan internal validitas butir instrumen keterampilan proses sains; 3) reliabilitas instrumen kemampuan berpikir kritis dan instrumen keterampilan proses sains; dan 4) karakteristik instrumen kemampuan berpikir kritis dan keterampilan proses. Jenis penelitian ini merupakan penelitian pengembangan Research and Development (R\&D) dan model pengembangan yang digunakan oleh Djemari Mardapi. Model ini terdiri atas tujuh tahap yang meliputi menyusun spesifikasi tes, menulis soal tes, menelaah soal tes, memperbaiki tes, melakukan uji coba, menganalisis tes, dan menafsirkan tes. Penelitian ini diuji cobakan pada siswa kelas V di SD No. 7 Benoa yang berjumlah 56 orang. Hasil penelitian menunjukkan bahwa: 1) Uji validitas butir kemampuan berpikir kritis 38 soal dalam kategori valid. Hasil uji reliabilitas sebesar 0,96 tergolong reliabel; 2) Uji internal konsistensi butir keterampilan proses sains 24 soal dalam kategori valid. Hasil uji reliabilitas sebesar 0,88 tergolong reliabel.
\end{abstract}

Kata kunci: Instrumen; Kemampuan Berpikir Kritis; Keterampilan Proses Sains

\begin{abstract}
This study aims to know and describe: 1) elements of the stage of development of critical thinking ability instruments and science process skills; 2) empirical validity of critical thinking ability instruments and internal validity of item instruments of science process skills; 3) reliability of critical thinking ability instruments and science process skills instruments; and 4) characteristics of critical thinking ability instruments and process skills. This type of research is research development Research and Development (R\&D) and development model used by Djemari Mardapi. This model consists of seven stages that include compiling test specifications, writing test questions, studying test questions, improving tests, conducting trials, analyzing tests, and interpreting tests. This study was tested on grade $V$ students at SD No. 7 Benoa which amounted to 56 people. The results showed that: 1) Test the validity of the item about critical thinking ability 38 points of the question in the category valid. The reliability test result of 0,96 is relatively reliable; 2) Test the validity of the item about the skill of the science process 24 points of the question in the category of valid. Reliability test result of 0,88 is relatively reliable.
\end{abstract}

Keywords: Instruments; Critical Thinking Ability; Science Process Skills

\section{PENDAHULUAN}

IImu pengetahuan dan teknologi telah mengubah dunia sekarang ini, perubahan begitu cepat dan luar biasa serta sangat kompleks. IImu pengetahuan dan teknologi tidak saja meningkatkan kesejahteraan dan intensitas komunikasi, tetapi juga menyebabkan perubahan pola pikir. Sumber daya manusia yang handal dan memadai secara berkualitas dapat diperoleh melalui sebuah pembelajaran. bagian yang sangat penting dan tidak dapat dipisahkan dari pembangunan nasional. Pembelajaran dijadikan pioner utama dalam penyiapan sumber daya 
manusia sebagai ketentuan mewujudkan pembangunan nasional sehingga pembelajaran menjadi suatu kebutuhan bagi setiap orang dalam menigkatkan kemampuan yang dimiliki. Perkembangan ilmu sains erat kaitannya dengan pembelajaran dalam hal perubahan dan perkembangan kurikulum dibidang teknologi. Minimnya pembelajaran sains dengan menerapkan kerja ilmiah menunjukkan bahwa kemampuan berpikir kritis dan keterampilan proses sains belum dilatihkan secara optimal. Jika keadaan ini secara terus berlangsung maka siswa tentu kesulitan mengaplikasikan pengetahuan yang diperolehnya di kelas dengan kehidupan nyata, oleh sebab itu diperlukan pengembangan pembelajaran sains yang melatih kemampuan berpikir pada diri siswa untuk memecahkan suatu masalah.

Salah satu kemampuan berpikir yang penting dikembangkan siswa adalah kemampuan berpikir kritis. Kemampuan berpikir kritis adalah kemampuan yang esensisal untuk kehidupan, pekerjaan dan berfungsi efektif dalam semua aspek kehidupan. Kemampuan berpikir kritis berkaitan dengan menganalisis, mengidentifikasi dan menganalisis masalah secara logis sehingga menghasilkan pertimbangan dan keputusan yang tepat. At the point when understudies think basically, they are urged to have an independent mind, to address speculations, to break down and blend the occasions, to go above and beyond by growing new theories and test them against current realities (Karakoc, 2016). Menurut Chism (1995) menyatakan bahwa berpikir kritis adalah mengaplikasikan rasional, aktivitas berpikir yang besar, yang meliputi aktivitas menganalisis, mensintesis, memahami kasus serta pemecahannya, merumuskan serta mengevaluasi. Globalisasi dan perkembangan ilmu pengetahuan teknologi dan komunikasi menunjukkan pengembangan kemampuan berpikir kritis merupakan suatu keharusan agar siswa dapat menyaring informasi, proses menyaring informasi hanya dapat dilakukan dengan baik dan benar oleh para pemikir kritis.
Septiasari (2020) menyatakan bahwa kemampuan berpikir kritis bisa jadi media seorang buat mengelola konflik intercultural. Aspek indikator berpikir kritis diklasifikasikan menjadi lima menurut Ennis (1985) yaitu, Elementary Clarification (memberikan penjelasan sederhana), The Basis for the Decision (menentukan dasar pengambilan keputusan), Inference (menarik kesimpulan), Advances Clarification (memberikan penjelasan lanjut) dan Supposition and Integration (Memperkirakan dan menggabungkan). Semakin baik kemampuan berpikir kritis ini dikembangkan siswa maka semakin baik pula kemampuan pemecahan masalah yang kompleks dengan hasil yang memuaskan. (Florea \& Hurjui, 2015) menyatakan basic reasoning is a method of drawing closer and tackling issue dependent on contention powerful, coherent and sane, which involvel checking, assessing and picking the right response to a given undertaking and contemplated dismissal of ather choices arrangements.

Berdasarkan pengetahuan tentang pendapatpendapat tersebut maka dapat disimpulkan bahwa kemampuan berpikir kritis merupakan suatu proses berpikir yang kompleks yaitu berpikir secara logis dan bertujuan untuk membuat keputusan yang masuk akal melalui proses ilmiah yang sistematis meliputi kegiatan menganalisis, mensinteis, mengenal permasalahan dan pemecahannya, menyimpulkan dan mengevaluasi.

Selain kemampuan berpikir kritis, Pembelajaran proses sains dalam konteks kurikulum 2013 dilakukan berdasarkan pada pendekatan ilmiah yang menuntut siswa untuk berpikir secara sistematis dan kritis dalam upaya memecahkan suatu masalah. Menurut Aktamis \& Ergin (2008) yang menyatakan keterampilan proses sains merupakan keahlian yang diperlukan oleh seorang buat memahami literasi sains, tingkatkan mutu hidup serta kepekaan alam dekat. Dari definisi yang dipaparkan tersebut, maka dapat disimpulkan bahwa keterampilan proses sains merupakan kemampuan individu dalam menerapkan metode ilmiah untuk 
memahami, mengembangkan serta menemukan ilmu pengetahuannya secara mandiri. Keterampilan proses sains tidak lain adalah jenis berpikir serta membangun uraian (Rauf, 2013). Rauf (2013) menyatakan keterampilan proses sains adalah perlengkapan buat menuntaskan permasalahan, perlengkapan yang digunakan siswa buat meningkatkan keahlian mentalnya, ialah keahlian berpikir tingkatan besar( higher order thinking skills) siswa, semacam keahlian berpikir kritis. Keterampilan proses sains pada dasarnya melatih kebiasaan berpikir siswa. Keterampilan proses sains dilaksanakan dengan menekankan pada bagaimana siswa belajar, bagaimana siswa mengolah masalahnya sehingga menjadi miliknya. Dari beberapa pendapat diatas kemampuan berpikir kritis adalah salah satu keterampilan berpikir tingkat tinggi yang berfokus untuk memutuskan apa yang mesti dipercaya atau dilakukan.

Keterampilan proses sains mengaitkan kemampuan kognitif, keterampilan psikomotor, dan sosial yang apabila dibelajarkan kepada siswa akan menjadi pembelajaran sains lebih bermakna. Dengan keterampilan proses siswa menemukan dan mengembangkan konsep dalam materi ajar. Other than quantitative abilities, a fundamental factor in science measure abilities is relational abilities on the grounds that fantastic relational abilities can be utilized as showing assets for graduate science instruction and undergrad science training and educational program improvement (Mercer-Mapstone \& Kuchel, 2017). Untuk mengukur sejauh mana keberhasilan keterampilan proses sains siswa maka harus diperhatikan beberapa indikator dari keterampilan proses sains tersebut. Keterampilan berpikir pada keterampilan proses sains digunakan buat mencerna data, membongkar permasalahan, serta merumuskan kesimpulan (Temiz et al., 2006). Melalui keterampilan proses sains, siswa tentunya juga akan mendapat pengertian yang tepat tentang hakikat ilmu pengetahuan sekaligus belajar proses dan produk ilmu pengetahuan.

Sains merupakan kumpulan dari pengetahuan dan bagaimana proses untuk dapat mengetahui pengetahuan, pembelajaran sains menggunakan metode ilmiah untuk dapat mengetahui kemampuan berpikir, bekerja dan bersikap ilmiah serta dapat mengomunikasikannya sebagai aspek penting pada pengalaman belajar secara langsung melalui pengembangan keterampilan proses. (Labouta et al., 2018) menyatakan bahwa science measure abilities can be acknowledged in the homeroom through learning science by doing science (LSDS) exercises, where this movement will support the real science research experience that drives understudies to think like researchers and to behave like researchers.

Suryaningsih (2017) menyatakan bahwa elajar dengan pendekatan keahlian proses membolehkan siswa menekuni konsep yang jadi tujuan belajar sains serta sekalian bisa meningkatkan keterampilanketerampilan dasar sains, perilaku ilmiah serta perilaku kritis. (Tilakaratne \& Ekanayake, 2017) menyatakan bahwa that science cycle abilities are significant and characterizes them as apparatuses to get data about the world, science measure abilities are viewed as ready to guarantee that the understudies get the significant learning experience since they help understudies to get higher request thinking. Sejalan dengan pendapat tersebut, menurut (Ango, 2002) yang menyatakan hence, the science interaction abilities is a significant part in the execution of learning since it can influence the advancement of understudies' information. Peran keterampilan proses sains dalam pembelajaran sangatlah penting dilihat dari keberhasilan belajar siswa. Melatih dan mengembangkan keterampilan proses sains pada siswa akan sangat berguna tidak hanya sebagai proses untuk membangun pengetahuan dalam pembelajaran tetapi berguna dalam kehidupan sehari-hari, sehingga keterampilan proses sains sangat 
penting dimiliki siswa karena sebagai persiapan menghadapi kenyataan hidup di masyarakat karena siswa dilatih berpikir logis dan kritis dalam menyelesaikan suatu permasalahan yang ada di masyarakat.

Ditinjau dari beberapa hal tersebut, guru akan lebih objektif dan efektif dalam menilai kemampuan berpikir kritis dan keterampilan proses sains dengan menggunakan instrumen. Guru dapat menggunakan jenis instrumen yang digunakan dalam proses pembelajaran Upaya untuk mencapai tujuan pembelajaran yang maksimal salah satunya dengan meningkatkan kualitas instrumen yang digunakan guru agar mampu mengembangkan kemampuan berpikir kritis dan keterampilan proses sains siswa. Berdasarkan hasil wawancara yang dilakukan bersama Ketua Gugus 1 Kuta Selatan didapatkan informasi tentang masalah yang dialami oleh siswa dalam proses penilaian hasil belajar di sekolah. Peneliti melakukan telaah instrumen penilaian yang digunakan. Instrumen yang telah tersedia tanpa adanya pengembangan oleh guru memiliki kualitas kurang baik. Instrumen tersebut belum mampu memenuhi keterampilan abad 21 sehingga siswa menjadi terbiasa mengerjakan instrumen dengan kemampuan berpikir rendah. Tuntutan zaman saat ini menjadikan guru mengubah mindset tentang hasil pembelajaran dengan mencapai tujuan pembelajaran abad 21. Agar siswa mampu mencapai keterampilan abad 21 maka guru harus memiliki instrumen yang relevan dengan memenuhi kebutuhan kemampuan berpikir kritis dan keterampilan proses sains siswa. Oleh sebab itu perlu adanya pengembangan instrumen berpikir dan untuk kemampuan keterampilan sains siswa.

$$
\text { Rumusan masalah dalam }
$$

penelitian ini yaitu sebagai berikut. (1) Bagaimana deskripsi unsur-unsur tahapan pengembangan instrumen kemampuan berpikir kritis dan keterampilan proses sains pada KD menganalisis siklus air dan dampaknya pada peristiwa di bumi serta kelangsungan mahluk hidup untuk siswa kelas V SD. (2) Bagaimana validitas empirik instrumen kemampuan berpikir kritis dan internal konsisten butir keterampilan proses sains pada KD menganalisis siklus air dan dampaknya pada peristiwa di bumi serta kelangsungan mahluk hidup untuk siswa kelas V SD. (3) Bagaimana reliabilitas instrumen pengembangan kemampuan berpikir kritis dan keterampilan proses sains pada KD menganalisis siklus air dan dampaknya pada peristiwa di bumi serta kelangsungan mahluk hidup untuk siswa kelas V SD. (4) Bagaimana karakteristik instrumen kemampuan berpikir kritis dan keterampilan proses sains pada KD menganalisis siklus air dan dampaknya pada peristiwa di bumi serta kelangsungan mahluk hidup untuk siswa kelas V SD.

Tujuan utama yang ingin dicapai dalam penelitian ini untuk menghasilkan pengembangan instrumen berpikir kritis dan instrumen keterampilan proses sains siswa kelas V SD dengan tujuan khususnya yaitu, (1) mengetahui dan mendeskripsikan unsur-unsur tahapan pengembangan instrumen kemampuan berpikir kritis dan keterampilan proses sains pada KD menganalisis siklus air dan dampaknya pada peristiwa di bumi serta kelangsungan mahluk hidup untuk siswa kelas V SD. (2) mengetahui dan mendeskripsikan tingkat validitas empirik instrumen kemampuan berpikir kritis dan internal konsistensi butir keterampilan proses sains pada KD menganalisis siklus air dan dampaknya pada peristiwa di bumi serta kelangsungan mahluk hidup untuk siswa kelas V SD. (3) mengetahui dan mendeskripsikan tingkat reliabilitas instrumen pengembangan kemampuan berpikir kritis dan keterampilan proses sains pada KD menganalisis siklus air dan dampaknya pada peristiwa di bumi serta kelangsungan mahluk hidup untuk siswa kelas V SD. (4) mengetahui dan mendeskripsikan karakteristik instrumen kemampuan berpikir kritis dan keterampilan proses sains pada KD menganalisis siklus air dan dampaknya pada peristiwa di bumi serta kelangsungan mahluk hidup untuk siswa kelas V SD. 


\section{METODE}

Penelitian ini menggunakan rancangan pengembangan Research and Development (R\&D) dengan model pengembangan yang dikembangkan oleh Djemari Mardapi. Model pengembangan tersebut terdiri dari sembilan tahapan akan tetapi pada langkah-langkah penelitian ini dimodifikasi menjadi tujuh tahapan yaitu, (1) menyusun spesifikasi tes (2) menulis soal tes (3) menelaah soal tes (4) memperbaiki tes (5) melakukan uji coba tes (6) menganalisis butir soal dan (7) menafsirkan hasil tes. Subjek dalam penelitian ini adalah siswa kelas $V$ di SD No. 7 Benoa dengan jumlah keseluruhan jumlah subjek pada penelitian ini 56 orang. Karakteristik siswa kelas V berada pada tahapan operasional konkret. Tahapan operasional konkret merupakan tahapan terakhir siswa kelas $\mathrm{V}$ karena siswa memiliki kemampuan logis dan sistematis, memecahkan masalah dan menyusun strategi. Metode pengumpulan data berupa suatu pernyataan tentang sifat, keadaan, kegiatan tertentu dan sejenisnya. Pengumpulan data dilakukan untuk mendapatkan suatu informasi yang dibutuhkan dalam mencapai tujuan penelitian. Data yang dikumpulkan dalam penelitian ini adalah berupa lembar validasi dan instrumen penilaian. Lembar validasi berupa format penelaahan instrumen penilaian butir soal yang bertujuan mengetahui ketepatan interpretasi instrumen penilaian tes bentuk pilihan ganda yang berjumlah 40 butir soal dan uraian yang berjumlah 25 butir soal.

Analisis validitas isi merupakan suatu analisis yang dilakukan dengan cara meninjau segi validitas dalam lembar validasi yang aspeknya meliputi, materi, konstruksi dan bahasa. Validasi instrumen dilakukan guna mengetahui validitas isi (content) dan reliabilitas instrumen. Analisis yang digunakan untuk mengukur validitas isi (content) dilakukan dengan menggunakan teknik Lawshe untuk menghitung Content Ratio Validity (CVR) dan reliabilitas instrumen diukur dengan menggunakan analisis
KR-21. Setelah melakukan validasi instrumen dilanjutkan dengan mengukur tingkat kepraktisan. Indikator kepraktisan sebuah bahan ajar meliputi kemudahan, kegunaan, dan kemenarikan.

Dalam mengukur validitas butir tes kemampuan berpikir kritis dalam bentuk objektif pilihan ganda digunakan rumus koefesien korelasi point biserial (rpbi). Nilai yang diperoleh kemudian dibandingkan dengan nilai yang diperoleh dari $r_{\text {tabel, }}$, jika $r_{\text {hitung }}>r_{\text {tabel }}$ maka dalam kategori valid. Selanjutnya internal konsistensi butir tes keterampilan proses sains dalam bentuk uraian digunakan rumus koefesien korelasi product moment. Nilai yang diperoleh kemudian dibandingkan dengan nilai yang diperoleh dari $r_{\text {tabel }}, r_{\text {hitung }}>r_{\text {tabel }}$, maka instrumen atau item pertanyaan berkorelasi signifikan terhadap skor total dinyatakan valid.

Uji daya beda pada penelitian ini dilakukan melalui rumus menentukan indeks diskriminasi. Pengujian daya beda hanya dilakukan pada instrumen kemampuan berpikir kritis. Butir tes dikatakan baik apabila mempunyai indeks diskriminasi berkisar 0,41 sampai dengan 0,70. Butir tes dengan kategori jelek tidak dipergunakan agar menghasilkan tes yang berkualitas. Indeks kesukaran penelitian ini merupakan bilangan yang menunjukkan sukar dan mudahnya sesuatu soal. Soal dengan indeks kesukaran 0,0 menunjukkan bahwa soal itu terlalu sukar, sebaliknya indeks 1,0 menunjukkan bahwa soalnya terlalu mudah. Pengujian indeks kesukaran hanya dilakukan pada instrumen kemampuan berpikir kritis.

Uji reliabilitas kemampuan berpikir kritis ditentukan dengan rumus Kuder Richadson (KR-21) dan uji reliabilitas keterampilan sains ditentukan dengan rumus Alpha Cronbach.

\section{HASIL DAN PEMBAHASAN}

Berdasarkan data terkumpul yang telah diolah, diperoleh hasil perhitungan data analisis expert sebagai berikut. 
Tabel 1. Rekapitulasi Hasil Perhitungan Analisis Expert

\begin{tabular}{cccccc}
\hline No & Instrumen & $\begin{array}{c}\text { Jumlah } \\
\text { Soal }\end{array}$ & CVR Indeks & $\begin{array}{c}\text { Nilai } \\
\text { Reliabilitas }\end{array}$ & Keterangan \\
\hline 1 & $\begin{array}{c}\text { Kemampuan berpikir } \\
\text { kritis }\end{array}$ & 40 soal & $\geq 0,60$ & 0,89 & $\begin{array}{c}\text { Valid dan } \\
\text { Reliabel }\end{array}$ \\
2 & $\begin{array}{c}\text { Keterampilan proses } \\
\text { sains }\end{array}$ & 25 soal & $\geq 0,60$ & 0,78 & $\begin{array}{c}\text { Valid dan } \\
\text { Reliabel }\end{array}$ \\
\hline
\end{tabular}

Berdasarkan Tabel 1 diatas dapat diketahui bahwa perhituangan analisis expert seluruh butir soal pada instrumen kemampuan berpikir kritis dengan jumlah 40 butir soal dinyatakan valid dan pengujian reliabilitas dengan KR-21 pada instrumen kemampuan berpikir kritis diperoleh koefisien reliabilitas instrumen $r_{11}$ sebesar 0,89. Karena $r_{11}>0,70$ menunjukkan bahwa instrumen kemampuan berpikir kritis dinyatakan telah reliabel, sehingga layak digunakan sebagai instrumen kemampuan berpikir kritis. Selanjutnya seluruh butir soal pada instrumen keterampilan proses sains dengan jumlah 25 butir soal dinyatakan valid dan diperoleh koefisien reliabilitas instrumen $r_{11}$ sebesar 0,78 menunjukkan bahwa instrumen keterampilan proses sains dinyatakan telah reliabel, sehingga layak digunakan sebagai instrumen keterampilan proses sains.

Setelah dilakukan uji validasi terhadap nilai yang diberikan oleh expert, maka dilanjutkan uji kepraktisan. Hasil uji kepraktisan ditunjukkan dalam Tabel 2 dibawah ini.

Tabel 2. Rekapitulasi Hasil Uji Kepraktisan

\begin{tabular}{ccccccc}
\hline No & Instrumen & Kemudahan & $\begin{array}{c}\text { Kegunaa } \\
\mathrm{n}\end{array}$ & $\begin{array}{c}\text { Kemena } \\
\text { rikan }\end{array}$ & $\begin{array}{c}\text { Rata- } \\
\text { rata }\end{array}$ & $\begin{array}{c}\text { Keteranga } \\
\mathrm{n}\end{array}$ \\
\hline 1 & $\begin{array}{l}\text { Kemampuan } \\
\text { berpikir kritis }\end{array}$ & 4,72 & 4,67 & 4,83 & 4,74 & $\begin{array}{c}\text { Sangat } \\
\text { praktis }\end{array}$ \\
2 & $\begin{array}{l}\text { Keterampilan } \\
\text { proses sains }\end{array}$ & 4,78 & 4,63 & 4,78 & 4,73 & $\begin{array}{c}\text { Sangat } \\
\text { Praktis }\end{array}$ \\
\hline
\end{tabular}

Berdasarkan Tabel 2 diatas dapat diketahui bahwa perhitungan uji kepraktisan instrumen kemampuan berpikir kritis diperoleh aspek kemudahan sebesar 4,72, nilai aspek kegunaan sebesar 4,67 , dan nilai ratarata aspek kemenarikan sebesar 4,83 dengan rata-rata 4,74 dengan kategori sangat praktis. Sedangkan perhitungan uji kepraktisan instrumen keterampilan proses sains diperoleh aspek kemudahan sebesar 4,78, nilai aspek kegunaan sebesar 4,63, dan nilai aspek kemenarikan sebesar 4,78 dengan ratarata 4,73 dengan kategori sangat praltis. Dengan demikian instrumen kemampuan berpikir kritis dan keterampilan proses sains terkategori sangat praktis dan layak untuk digunakan.

Setelah dilakukan uji kepraktisan terhadap nilai yang diberikan oleh praktisi, maka dilanjutkan uji analisis butir. Hasil uji analisis butir ditunjukkan dalam Tabel 3 dibawah ini.

Tabel 3. Rekapitulasi Hasil Perhitungan Analisis Butir

\begin{tabular}{cccccccc}
\hline No & Instrumen & Analisis & $\begin{array}{c}\text { Uji } \\
\text { Validitas } \\
\text { Butir }\end{array}$ & $\begin{array}{c}\text { Uji } \\
\text { Daya } \\
\text { Beda }\end{array}$ & $\begin{array}{c}\text { Uji Indeks } \\
\text { Kesukaran }\end{array}$ & $\begin{array}{c}\text { Nilai } \\
\text { Reliabilitas }\end{array}$ & $\begin{array}{c}\text { Ketera } \\
\text { ngan }\end{array}$ \\
\hline Koefesien & $\begin{array}{l}\text { Konampuan } \\
\text { korelasi }\end{array}$ & $\begin{array}{l}38 \text { soal } \\
\text { point } \\
\text { biserial } \\
\text { (rpbi) }\end{array}$ & $\begin{array}{c}0,41- \\
\text { valid }\end{array}$ & $\begin{array}{c}0,70 \\
\text { (Kriteria } \\
\text { berpikir kritis }\end{array}$ & $\begin{array}{c}0,66 \\
\text { (Kategori } \\
\text { sedang) }\end{array}$ & 0,96 & $\begin{array}{c}\text { Reliabe } \\
\text { I }\end{array}$ \\
\hline
\end{tabular}




\begin{tabular}{|c|c|c|c|c|c|c|c|}
\hline No & Instrumen & Analisis & $\begin{array}{c}\text { Uji } \\
\text { Validitas } \\
\text { Butir }\end{array}$ & $\begin{array}{c}\text { Uji } \\
\text { Daya } \\
\text { Beda }\end{array}$ & $\begin{array}{l}\text { Uji Indeks } \\
\text { Kesukaran }\end{array}$ & $\begin{array}{c}\text { Nilai } \\
\text { Reliabilitas }\end{array}$ & $\begin{array}{c}\text { Ketera } \\
\text { ngan }\end{array}$ \\
\hline 2 & $\begin{array}{l}\text { Keterampilan } \\
\text { proses sains }\end{array}$ & $\begin{array}{l}\text { Koefesien } \\
\text { korelasi } \\
\text { product } \\
\text { moment }\end{array}$ & $\begin{array}{l}24 \text { soal } \\
\text { valid }\end{array}$ & - & - & 0,88 & $\begin{array}{c}\text { Reliabe } \\
\text { I }\end{array}$ \\
\hline
\end{tabular}

Berdasarkan Tabel 3 diatas, dapat diketahui bahwa analisis validitas butir kemampuan berpikir kritis dalam bentuk objektif pilihan ganda digunakan rumus koefesien korelasi point biserial (rpbi). Dari 40 soal yang telah diujikan dengan dengan $r_{\text {tabel }}$ maka diperoleh pada instrumen kemampuan berpikir kritis terdapat 38 butir soal dalam kategori valid dan 2 soal dalam kategori tidak valid. Selanjutnya internal konsistensi butir keterampilan proses sains dalam bentuk uraian digunakan rumus koefesien korelasi product moment. Dari 25 soal yang telah diujikan dengan dengan $r_{\text {tabel }}$ maka diperoleh pada instrumen keterampilan proses sains terdapat 24 soal dalam kategori valid dan 1 soal dalam kategori tidak valid. Pengujian daya beda butir soal dianalisis menggunakan bantuan Microsoft Excel. Uji daya beda tes dilakukan pada instrumen kemampuan berpikir kritis. Sebelum menguji daya pembeda dengan rumus indeks diskriminasi, seluruh testee diurut mulai dari siswa (testee) yang memperoleh skor tertinggi hingga terendah. Kemudian, untuk penentuan kelompok atas dan bawah ditentukan dengan mengambil kutubnya saja, yaitu $27 \%$ skor teratas sebagai kelompok atas (JA) dan $27 \%$ skor terbawah sebagai kelompok bawah (JB). Sesuai dengan kriteria yang telah ditentukan maka hasil pengujian daya pembeda diperoleh 38 soal dengan kriteria baik.

Perhitungan uji indeks kesukaran menggunakan bantuan Microsoft Excel. Uji indeks kesukaran dilakukan pada instrumen kemampuan berpikir kritis. Sesuai dengan kriteria penilaian yang ditentukan, maka diperoleh indeks kesukaran butir soal yaitu butir soal dengan kriteria sedang 34 soal, dan butir soal dengan kriteria mudah 4 soal. Untuk indeks kesukaran perangkat tes yaitu 0,66 dengan kategori sedang. Dalam penelitian ini perhitungan reliabilitas dianalisis menggunakan bantuan Microsoft Excel. Nilai reliabilitas instrumen kemampuan berpikir kritis dihitung dengan menggunakan rumus Kuder Richadson (KR-21). Dari 38 soal yang dinyatakan valid maka diperoleh $r_{11}=0,96>0,70$ artinya bahwa soal pilihan ganda pada penelitian ini tergolong reliabel. Selanjutnya nilai reliabilitas butir soal instrumen keterampilan proses sains dihitung dengan menggunakan rumus Alpha Cronbach. Dari 24 soal yang dinyatakan valid maka diperoleh $r_{11}=0,88>0,70$ artinya bahwa soal tes uraian pada penelitian ini tergolong reliabel.

Ennis (1993) menyatakan bahwa kemampuan berpikir kritis adalah keahlian berpikir secara reflektif serta logis yang berfokus pada perihal yang wajib dicoba buat bisa menuntaskan sesuatu kasus yang dialami. Berdasarkan penelitian yang dilakukan (Frijters, 2008) yang menyatakan bahwa bila seorang mempunyai keahlian berpikir kritis yang kurang, hingga orang tersebut hendak kesusahan buat bersaing di dunia global. Sejalan dengan hal tersebut (Pradana et al., 2017) yang menyatakan bahwa bila seorang yang mempunyai keahlian berpikir kritis hingga orang tersebut bisa turut dan berfungsi selaku konsumen sains. Pendidikan saat ini sangat perlu melatih siswa agar memiliki kemampuan berpikir kritis sehingga memiliki kemampuan bersikap dan berperilaku adaptif dalam menghadapi tantangan dan tuntutan kehidupan sehari-hari. That 
understudies should master thinking and thinking abilities to understand their fullest potential in the present society (Alghafri \& Ismail, 2014)). Kemampuan berpikir kritis sangat diperlukan untuk menganalisis suatu permasalahan hingga pada tahap pencarian solusi untuk menyelesaikan permasalahan tersebut. Orang yang memiliki kemampuan berpikir kritis tidak hanya mengenal sebuah jawaban. Mereka akan mencoba mengembangkan kemungkinan-kemungkinan jawaban lain berdasarkan analisis dan informasi yang telah didapat dari suatu permasalahan. Kemampuan berpikir kritis bisa digunakan siswa dalam mendengarkan bermacam komentar orang lain yang sama ataupun berbeda (Suarjana, 2020). Selain kemampuan berpikir kritis, keterampilan proses sains merupakan keterampilan yang penting bagi siswa. Keterampilan proses sains bisa melatihkan pembiasaan dalam berpikir ilmiah buat membongkar kasus (Husen, 2017).

Adanya pengembangan instrumen ini akan menjadikan pengukuran terhadap kemampuan kognitif siswa menjadi lebih optimal. Pengaplikasian tersebut mampu mengembangkan kemampuan pemahaman berpikir kritis dan keterampilan proses sains siswa. Hal ini didukung juga dalam penelitian Mukti dan Istiyono (2018) yang menyatakan bahwa instrumen pengujian memiliki nilai kehandalan yang tinggi dan instrumen uji mengalami kesulitan yang baik tingkat kriteria. Selanjutnya Penelitian yang dilakukan oleh Dadri (2019) dengan judul penelitian "Pengaruh Model Pembelajaran Kooperatif tipe NHT terhadap Kemampuan Berpikir Kritis dan Hasil Belajar Matematika Siswa Kelas V SD Gugus III Mengwi" yang menyatakan bahwa terdapat pengaruh yang signifikan model pembelajaran kooperatif tipe NHT secara simultan terhadap kemampuan berpikir kritis dan hasil belajar matematika. Sejalan dengan pendapat tersebut menurut (Maulana, 2017:5) yang menyatakan berpikir kritis sangat diperlukan oleh setiap orang untuk menyikapi permasalahan dalam realita kehidupan yang tidak bisa dihindari.

(Matthews et al., 2015) menyatakan bahwa science measure abilities can likewise be used to further develop understudies understanding insights about their quantitative abilities. Pembelajaran sains mengarah pada kebiasaan yang memungkinkan siswa tidak hanya mempelajari pengetahuan yang mengarah pada keterampilan berpikir yang dapat menghasilkan konsep dan teori tetapi pembelajaran sains mempelajari tentang pengetahuan prosedural, belajar tentang bagaimana cara memperoleh informasi melalui kegiatan ilmiah yang berbasis pada keterampilan proses sains. Sejalan dengan pendapat tersebut dalam penelitian IImi (2016) yang menyampaikan bahwa instrumen penilaian keterampilan proses sains yang dikembangkan layak digunakan untuk mengukur keterampilan proses sains siswa secara spesifik. Selanjutnya penelitian yang dilakukan oleh Kotimah (2019) dengan judul "Pengembangan Instrumen Assessment Sikap Ilmiah Dan Keterampilan Proses Sains Dengan Scientific Approach" yang menyatakan bahwa kesesuaian instrumen penilaian sikap ilmiah dan keterampilan proses diperoleh sekor 3,48 dengan kategori sangat sesuai, kemanfaatan dan kemudahan instrumen penilaian sikap ilmiah dan keterampilan proses diperoleh sekor 3,44 dan 3,46 dengan kategori sangat bermanfaat dan sangat mudah digunakan.

Berdasarkan

tahapan pengembangan yang dilakukan, instrumen kemampuan berpikir kritis dan keterampilan proses sains memiliki karakteristik sebagai berikut. (1) komponen instrumen, (2) bentuk tes, (3) tingkatan kognitif instrumen, (4) tampilan instrumen dan (5) materi soal. Penelitian ini menghasilkan produk berdasarkan temuan-temuan dari serangkaian uji coba melalui kelompok sedang dan uji lapangan yang kemudian dilakukan 
revisi untuk mendapatkan hasil dan produk yang memadai atau layak dipakai, sedangkan pada penelitian sebelumnya tidak dimaksudkan untuk menghasilkan produk atau desain tetapi menemukan pengetahuan baru melalui penelitian dasar atau untuk menjawab permasalahan-permasalahan praktis di lapangan melalui penelitian terapan.

Keterbatasan yang ada dalam penelitian ini adalah sebagai berikut. (1) Subjek dalam penelitian ini hanya siswa kelas V di SD No. 7 Benoa, untuk penelitian lebih lanjut dapat menggunakan subjek uji coba yang lebih luas untuk meningkatkan keakuratan soal yang dikembangkan; (2) Penelitian ini dibatasi pada pengembangan instrumen kemampuan berpikir kritis dan instrumen keterampilan proses sains Tema $8 \mathrm{KD}$ 3.8 Menganalisis siklus air dan dampaknya pada peristiwa di bumi serta kelangsungan mahluk hidup siswa kelas V SD; (3) Kegiatan uji coba instrumen peneliti hanya mampu menyebarkan instrumen melalui aplikasi google form, disebabkan karena situasi pandemi yang tidak memungkinkan dilakukannya kegiatan di lapangan. Hal ini merupakan keterancaman terhadap validitas internal penelitian yang diatasi dengan ketepatan waktu yang digunakan siswa mengupload respon atau jawaban.

\section{PENUTUP}

IImu pengetahuan dan teknologi tersebut adalah variabel yang paling berpengaruh terhadap pembelajaran. Pembelajaran selalu melakukan adaptasi dengan gerak perkembangan ilmu pengetahuan modern dan inovasi teknologi maju, Upaya dalam mencapai tujuan pendidikan yang optimal salah satunya adalah kualitas instrumen yang digunakan oleh guru agar mampu mengembangkan kemampuan berpikir siswa. Minimnya pembelajaran sains dengan menerapkan kerja ilmiah tersebut, menunjukkan bahwa kemampuan berpikir kritis dan keterampilan proses sains belum dilatihkan secara optimal.

Pada penelitian ini instrumen kemampuan berpikir kritis dan instrumen keterampilan proses sains diberikan kepada 5 orang expert yang terdiri dari 2 dosen dan 3 praktisi. Berdasarkan analisis data yang telah dilakukan dengan pengujian validitas isi menggunakan teknik Lawshe untuk menghitung Content Validity Ratio (CVR) dan pengujian reliabilitas menggunakan KR-21 dapat diketahui bahwa instrumen kemampuan berpikir kritis dan instrumen keterampilan proses sains memenuhi validitas isi (content) berdasarkan expert dan memiliki reliabilitas yang tinggi. Nilai yang diperoleh dari pengujian reliabilitas instrumen kemampuan berpikir kritis adalah 0,89 dan nilai yang diperoleh dari pengujian reliabilitas instrumen keterampilan proses sains adalah 0,78. Dengan demikian dapat disimpulkan bahwa instrumen kemampuan berpikir kritis dan instrumen keterampilan proses sains telah memiliki validitas isi dan reliabilitas yang tinggi.

Setelah melakukan uji validasi langkah selanjutnya diuji kepraktisan dari soal tersebut didapatkan nilai dengan rata-rata 4,74 dengan kategori sangat praktis. Sedangkan perhitungan uji kepraktisan instrumen keterampilan proses sains diperoleh rata-rata 4,73 dengan kategori sangat praltis. Dengan demikian instrumen kemampuan berpikir kritis dan keterampilan proses sains terkategori sangat praktis dan layak untuk digunakan. Kemudian dilanjutkan dnegan analisis butir, soal tersebut diuji cobakan kepada subjek. Kelas yang dipilih adalah kelas $\mathrm{V}$ dengan jumlah 56 orang. Instrumen kemampuan berpikir kritis bentuk pilihan ganda untuk pembelajaran IPA SD yang dihasilkan dalam penelitian ini telah memenuhi kriteria soal yang baik. Bukti bahwa instrumen kemampuan berpikir kritis yang dikembangkan telah memenuhi kriteria yang baik adalah sebagai 
berikut, Uji Validitas butir kemampuan berpikir kritis dalam telah diujikan dengan dengan $r_{\text {tabel }}$ maka diperoleh pada instrumen kemampuan berpikir kritis terdapat 38 butir soal dalam kategori valid, Hasil pengujian daya pembeda diperoleh 38 butir soal dengan kriteria baik, uji indeks kesukaran butir soal kemampuan berpikir kritis yaitu butir soal dengan kriteria sedang 34 soal, dan butir soal dengan kriteria mudah 4 soal. Untuk indeks kesukaran perangkat tes yaitu 0,66 dengan kategori sedang dan reliabilitas instrumen kemampuan berpikir kritis dihitung dengan menggunakan rumus Kuder Richadson (KR-21). Dari 38 soal yang dinyatakan valid maka diperoleh r11 $=0,96>0,70$ artinya bahwa soal tes pilihan ganda pada penelitian ini tergolong reliabel.

Instrumen keterampilan proses sains bentuk uraian untuk pembelajaran IPA SD yang dihasilkan dalam penelitian ini telah memenuhi kriteria soal yang baik. Bukti bahwa instrumen keterampilan proses sains yang dikembangkan telah memenuhi kriteria yang baik adalah sebagai berikut. Internal konsistensi butir keterampilan proses sains dalam telah diujikan dengan dengan $r_{\text {tabel }}$ maka diperoleh pada instrumen keterampilan proses sains terdapat 24 soal dalam kategori valid, dan nilai reliabilitas butir soal instrumen keterampilan proses sains dihitung dengan menggunakan rumus Alpha Cronbach. Dari 24 soal yang dinyatakan valid maka diperoleh $\mathrm{r} 11=$ $0,88>0,70$ artinya bahwa soal tes uraian pada penelitian ini tergolong reliabel.

Sebagai bentuk tindak lanjut dari hasil penelitian yang diperoleh, adapun saran yang dapat diajukan dalam penelitian ini adalah sebagai berikut. (1) guru perlu berlatih untuk menciptakan instrumen yang mampu mengembangkan proses sains siswa. Sehingga penilaian terhadap penguasaan materi siswa lebih bermakna; (2) instrumen kemampuan berpikir kritis dan instrumen keterampilan proses sains ini dapat digunakan untuk bahan penelitian selanjutnya bagi peneliti lain. Hasil analisis ini dapat dijadikan contoh pengembangan instrumen dan memberikan masukan pada bidang pendidikan khususnya; (3) lembaga pendidikan merupakan wadah tumbuh kembang siswa dengan berbagai proses pendidikan. Sekolah diharapkan mampu mendorong kreativitas guru dan siswa dalam segala bentuk pembelajaran.

\section{DAFTAR RUJUKAN}

Aktamis, H., \& Ergin, O. (2008). The Effect of Scientific Process Skills Education on Students' Scientific Creativity, Science Attitudes and Academic Achievements. AsiaPacific Forum on Science Learning and Teaching.

Alghafri, A. S. R., \& Ismail, H. N. Bin. (2014). The Effects of Integrating Creative and Critical Thinking on Schools Students' Thinking. International Journal of Social Science and Humanity. https://doi.org/10.7763/ijssh.2014. v4.410

Ango, M. (2002). Mastery of Science Process Skills and Their Effective Use in the Teaching of Science: An Educology of Science Education in the Nigerian Context. Online Submission.

Chism, N. V. N., Angelo, T. A., \& Cross, K. P. (1995). Classroom Assessment Techniques: A Handbook for College Teachers. The Journal of Higher Education. https://doi.org/10.2307/2943957

Dadri, P. C. W., Dantes, N., \& Gunamantha, I. M. (2019). Pengaruh Model Pembelajaran Kooperatif tipe NHT terhadap Kemampuan Berpikir Kritis dan Hasil Belajar Matematika Siswa Kelas V SD Gugus III Mengwi. PENDASI: Jurnal Pendidikan Dasar Indonesia, 3(2), 84-93. 
Dan, K., Peduli, S., Tema, L., Suarjana, I. M., Lasmawan, I. W., \& Gunamantha, I. M. (2020). PENGEMBANGAN INSTRUMEN KEMAMPUAN BERPIKIR Universitas Pendidikan Ganesha. 4(2), 101-111.

Ennis, R. H. (1985). A Logical Basis for Measuring Critical Thinking Skills. In Educational Leadership. https://doi.org/10.3102/003465431 0376953

Ennis, R. H. (1993). Critical thinking assessment. Theory Into Practice. https://doi.org/10.1080/004058493 09543594

Erlina Kusnul Kotimah , Undang Rosidin, I. W. (2019). Pengembangan instrumen assessment sikap ilmiah dan keterampilan proses sains dengan scientific approach. 1-122.

Florea, N. M., \& Hurjui, E. (2015). Critical Thinking in Elementary School Children. Procedia - Social and Behavioral Sciences, 180, 565-572.

https://doi.org/10.1016/j.sbspro.20 15.02.161

Frijters, S., ten Dam, G., \& Rijlaarsdam, G. (2008). Effects of dialogic learning on value-loaded critical thinking. Learning and Instruction. https://doi.org/10.1016/j.learninstru c.2006.11.001

Husen, A., Indriwati, S. E., \& Lestari, U. (2017). Peningkatan Kemampuan Berpikir Kritis Dan Keterampilan Proses Sains Siswa Sma Melalui Implementasi Problem Based Learning Dipadu Think Pair Share. Teori, Penelitian, Dan Pengembangan.

IImi, N., Desnita, D., Handoko, E., \& Zelda, B. (2016). Pengembangan Instrumen Penilaian Keterampilan Proses Sains Pada Pembelajaran Fisika Sma. V, SNF2016-RND-57SNF2016-RND-62. https://doi.org/10.21009/03050102 13

Karakoc, M. (2016). The Significance of Critical Thinking Ability in Terms of Education. International Journal of Humanities and Social Science.

Labouta, H. I., Kenny, N. A., Li, R., Anikovskiy, M., Reid, L., \& Cramb, D. T. (2018). Learning science by doing science: an authentic science process-learning model in postsecondary education. International Journal of Science Education.

https://doi.org/10.1080/09500693. 2018.1484966

Matthews, K. E., Adams, P., \& Goos, M. (2015). The Influence of Undergraduate Science Curriculum Reform on Students' Perceptions of their Quantitative Skills. International Journal of Science Education. https://doi.org/10.1080/09500693. 2015.1096427

Mercer-Mapstone, L., \& Kuchel, L. (2017). Core Skills for Effective Science Communication: A Teaching Resource for Undergraduate Science Education. International Journal of Science Education, Part B: Communication and Public Engagement. https://doi.org/10.1080/21548455. 2015.1113573

Pradana, S. D. S., Parno, P., \& Handayanto, S. K. (2017). Pengembangan tes kemampuan berpikir kritis pada materi Optik Geometri untuk mahasiswa Fisika. Jurnal Penelitian Dan Evaluasi Pendidikan.

https://doi.org/10.21831/pep.v21i1. 13139

Rauf, R. A. A., Rasul, M. S., Mansor, A. N., Othman, Z., \& Lyndon, N. (2013). Inculcation of science 
process skills in a science classroom. Asian Social Science. https://doi.org/10.5539/ass.v9n8p4 7

Septiasari, P., Dantes, N., \& Suastra, W. (2020). PENGARUH MODEL RECIPROCAL TEACHING BERBASIS PENDEKATAN SAINTIFIK TERHADAP KEMAMPUAN BERPIKIR KRITIS DAN HASIL BELAJAR IPA KELAS V. 4(1), 85-94.

Suryaningsih, Y. (2017). Pembelajaran Berbasis Praktikum Sebagai Sarana Siswa Untuk Berlatih Menerapkan Keterampilan Proses Sains Dalam Materi Biologi. Jurnal Bio Education, 2, 49-57.

Temiz, K. B., Taşar, M. F., \& Tan, M. (2006). Development and validation of a multiple format test of science process skills. International Education Journal.

Tilakaratne, C. T. K., \& Ekanayake, T. M. S. S. K. Y. (2017). Achievement level of Science Process Skills of Junior Secondary Students: Based on a Sample of Grade Six and Seven Students from Sri Lanka. International Journal of Environmental \& Science Education. 